\title{
KOMPONEN SISTEM HEMATOPOITIK SEBAGAI BIOINDIKATOR TINGKAT KETERPAPARAN RADIASI PADA PEKERJA/OPERATOR RADIOLOGI
}

\section{(THE COMPONENT OF HEMATOPOITIC SYSTEM AS BIOINDICATOR IN THE LEVEL OF RADIATION TO THE RADIOLOGIST OPERATOR)}

\author{
Terubus \\ Puskesmas Krian Dinas Kesehatan Kabupaten Sidoarjo \\ Jl. Setyabudi, Krian, Sidoarjo 61262 \\ e-mail: rosulinandananda@yahoo.co.id
}

\begin{abstract}
ABSTRAK
Pemantauan dosis radiasi secara biologi memberikan kontribusi penting terhadap perkiraan dosis kumulatif paparan radiasi dalam studi epidemiologi khususnya dalam kasus tanpa keberadaan dosimeter fisika. Tujuan penelitian untuk mengetahui tingkat paparan radiasi pada operator radiologi dengan menganalisis kompartemen darah, yang meliputi jumlah total sel darah putih, limfosit, monosit, neutrofil, eosinofil, basofil, total sel darah merah, PCV, hemoglobin, dan trombosit. Secara statistik tidak ada perbedaan bermakna antara variabel kompartemen darah dengan umur, jenis kelamin, masa kerja, frekuensi paparan. Sample pada penelitian adalah semua operator (radiographer) di Instalasi radiodiagnostik RSU Dr Wahidin Sudiro Husodo Mojokerto. Hasil analisis sistem hematologi dibandingkan dengan petugas adsminitrasi (non paparan). Dan ada perbedaan bermakna antara variabel frekuensi paparan dengan diagnostik colon in loop, di mana jumlah analisis leukosit $\mathrm{p}=0,041<$ alfa $=0,05$ dan hemoglobin $\mathrm{p}=$ $0,044<$ alfa $=0,05$. Dari hasil pemantauan paparan radiasi lingkungan kerja $=0,37$ miuSv miuSv/jam, sudah memenuhi standar yang berlaku. Hal ini telah sesuai dengan surat keputusan Kepala Badan Pengawas Tenaga Nuklir nomor: 01/KA-BAPETEN/ $\mathrm{V}-99$. Di mana dosis lingkungan kerja adalah $<25$ miuSv miuSv/jam (2,5 mRem/Jam). Dari hasil penelitian dan analisis data dapat disimpulkan bahwa dosis paparan pada operator radiologi berupa penuruman jumlah kompartemen leukosit, eritrosit, PCV
\end{abstract}

dan hemoglobin. Sistem proteksi radiasi harus ditunjang dengan sistem manajemen proteksi radiasi dan perbaikan berkelanjutan sesuai dengan perkembangan yang ada.

Kata kunci: sistem hematologi, dosis paparan, sinar hambur, pengendalian radisi

\section{ABSTRACT}

Biological monitoring of radiographers gives an importants information of cumulative dose of radiation exposure. This information will be more important if the radiographers doesn't use personal monitoring film badge. The research was a crossectional analytical study: The purpose of the research was known the level of radiation exposure among the radiographers in Hospital Dr Wahidin Sudiro Husodo. The population of the study were all radiographer in hospital Dr Wahidin Sudiro Husodo as much 7 people. The control of study was the adsminitration staff as much as 5 people. Indicators of radiation exposure were leukocytes, lymphocytes, monocytes, neutrophyls, eosinophyl, basofyl, errythrocytes, PCV, hemoglobin and platelets. The result of the study were leukocyte $(p>0,05)$. limfosyt $(p>0,05)$, monosyt $(p>0,05)$, neutrofyl $(p>0,05)$, eosinofyl $(p>$ $0,05)$, basofyl (an detection), eritrosit $(p>0.05)$. PCV $(p>0,05)$, hemoglobin $(p>0,05)$, platelets $(p>0,05)$. Conclution of the study was no 
difference signification among all variable of the study it means the blood indicator couldn't used as indicator of radiation exposure. Recomendations the research concerning the radiographer impact should here an adequate sample number:

\section{Keywords: hematology system, exposure dose, ray scattering, radiation control.}

\section{LATAR BELAKANG}

Pemanfaatan radiasi pengion dalam bidang radiodiagnostik untuk berbagai keperluan medik perlu memperhatikan dua aspek, yaitu resiko dan manfaat yang dicapai. Fakta menunjukkan bahwa instalasi radiologi bisa sangat rawan jika pemantauan dosis serap dan pengukuran paparan dan kebocoran radiasi tidak dilakukan. Dampaknya secara langsung akan dirasakan oleh radiografer, karena sinar hambur dari alat yang menghasilkan sinar- $\mathrm{X}$ dapat mengionisasi pada materi yang dilaluinya. Petugas operator radiologi adalah orang yang bekerja di medan radiasi, sehingga besar kemungkinan akan terpapar oleh sinar hambur tersebut. Karena sifat dari sinar- $X$ dapat mengionosasi pada materi yang dilaluinya, maka perkerja atau operator radiologi besar kemungkinannya akan mengalami gangguan kesehatan (Turniani, 2002). Dalam pelayanan kesehatan RSU Dr Wahidin Sudiro Husodo memanfaatkan radiasi pengion dalam bidang radiodiagnostik untuk berbagai keperluan medis. Dari pemanfaatan radiodiagnostik X-Ray mempunyai resiko besar terhadap kesehatan pekerja operator (fotografer), dan tenaga kerja lainnya yang berkecimpung di dalamnya. Instalasi radiodiagnostik RSU Dr Wahidin Sudiro Husodo belum pernah melakukan evaluasi paparan radiasi lingkungan kerja dengan melakukan kalibrasi terhadap alat $X$-Ray. Sehingga belum diketahui pula berapa besaran papan radiasi lingkungan kerja tersebut. Dan program pengendalian bahaya radisi di instajasi radiodiagnostik belum berjalan dengan baik, dalam arti ijin operasional dari BAPETEN belum ada, dan salah satu persyaratan dari ijin tersebut adalah pengkuran paparan radiasi lingkungan kerja (Badan Tenaga Atom Nasional. 2002).

Prevalensi mengenai efek menugikan yang muncul pada tubuh manusia karena terpapar sinar- $X$ tersebut berupa kerontokan rambut dan kerusakan kulit. Pada tahun 1897 di Amerika Serikat dilaporkan adanya 69 kasus kerusakan kulit yang disebabkan oleh sinar-X. Sedang pada tahun 1902, angka yang dilaporkan meningkat menjadi 170 kasus. Pada tahun 1911 di Jerman juga dilaporkan adanya 94 kasus tumor yang disebabkan oleh sinar-X telah teramati, namun upaya perlindungan terhadap penyinaran sinar- $X$ belum terpikirkan. Marie Curie, penemu bahan radioaktif polonium dan radium meninggal pada tahun 1934 akibat terserang leukimia. Penyakit tersebut besar kemungkinan akibat paparan radiasi karena seringnya beliau berhubungan dengan bahan-bahan radioaktif (Akhadi dan Mukhlis, 2000). Di Indonesia kecelakaan radiasi terjadi pada bulan Januari 1998 di salah satu rumah sakit, yang menewaskan satu orang. Rumah sakit memang salah satu pengguna cukup besar dalam pemanfaatan tenaga nuklir. Data dari Bapeten menunjukkan sebanyak 24 rumah sakit di Indonesia memanfaatkan radiasi untuk radiodiagnosis (pemeriksaan) dan radioterapi (pengobatan). Beberapa bahan radioaktif yang banyak digunakan rumah-rumah sakit tersebut, adalah Co (Cobalt 60), Ra-226, Cs137, Ir-192, I-125, SR-90, Am-241, I-153, dan lainnya. Pada survei awal di RSU Dr Wahidin Sudiro Husodo diketahui bahwa tenaga kerja fotografer tidak dilengkapi personal monitoring film badge. Dari hasil catatan rekapitulasi dosis serap pada tahun 2008 dan sebelumnya beberapa film badge yang permah dianalisis sebelumnya telah tercatat melebihi batas dosis yang telah ditetapkan oleh Keputusan Kepala Badan Pengawas Tenaga Nuklir Nomor 01 / KaBAPETEN/V-99 (50 miuSV per tahun) atau 0,417 $\mathrm{mRm}$ per bulan, di mana salah seorang radiografer telah terpapar sebesar 0,44 miuSV dalam satu bulan.

Sesuai dengan Peraturan Pemerintah No 33 Tahun 2007, pasal 32 setiap pekerja, pasien, pendamping pasien atau orang lain yang berhubungan dengan radiasi wajib memakai pemantau dosis perorangan dan peralatan protektsi radiasi sebagaimana dimaksud dalam Pasal 31 ayat (2) huruf a dan huruf b (Heryudo, 2003). Dengan demikian, untuk kepentingan kesehatan dan keselamatan terhadap pemanfaatan radiasi pengion perlu adanya pengukuran paparan radiasi atau sinar hambur untuk proteksi radiasi, dengan tujuan memberikan perlindungan terhadap pekerja, penderita, dan masyarakat di sekitar area radiasi. Sebagai ketentuan dalam undang-undang bahwa, setiap pengguna zat radioaktif atau sumber radiasi pengion lainnya harus memiliki alat ukur proteksi radiasi. Alat ukur proteksi radiasi dibedakan menjadi tiga jenis yaitu dosimeter perorangan, surveimeter, dan monitor kontaminasi (BAPETEN, 2001). Dosimeter perorangan adalah sejenis alat yang mempunyai sensitifitas yang tinggi terhadap radiasi sinar- $\mathrm{X}$. Alat ini yang dipakai oleh pekerja operator radiologi, dengan tujuan untuk memonitor besaran paparan terhadap sinar hambur 
yang diterimanya selama bekerja di medan radiasi. Untuk keperluan proteksi radiasi, selain pemantauan dosis perorangan, diperlukan pula adanya pemantauan radiasi dan radioaktivitas lingkungan. Pemantauan radiasi lingkungan kerja untuk mengetahui tingkat kebocoran sinar hambur daerah kerja secara langsung. Instrumen fisika untuk pemantauan lingkungan ini secara garis besar dapat dikelompokkan ke dalam tiga jenis, dan yang paling sering digunakan adalah surveymeter radiasi. Surveymeter radiasi merupakan alat monitoring yang dipakai untuk mengukur tingkat radiasi dan biasanya memberikan data hasil pengukuran dalam laju dosis (dosis radiasi persatuan waktu), dalam mrem/jam, miuSvijam. Surveymeter kontaminasi permukaan merupakan alat yang dipakai untuk mengukur tingkat kontaminasi radioaktif pada suatu permukaan dan biasanya memberikan data dalam bentuk hasil cacahan per satuan waktu. Data ini dapat dikonversikan (diolah lebih lanjut) menjadi tingkat kontaminasi persatuan luas (Badan Tenaga Atom Nasional, 2002). Untuk pengukuran paparan radiasi di sekitar tabung pada pesawat X-Ray, tolok ukur tingkat paparan radiasi tidak boleh lebih dari 100 $\mathrm{mr} / \mathrm{jam}$. Sedangkan paparan radiasi sesuai dengan prosedur pemeriksaan yaitu tolok ukur tingkat paparan radiasi yang ditempati oleh pekerja radiasi tidak boleh melebihi 2,5 mr/jam, untuk pendudak umum tidak bolch melebihi $0,25 \mathrm{mr} / \mathrm{jam}$ (Siemens, 2003). Efek merugikan dapat muncul apabila tubuh manusia mendapatkan paparan radiasi melebihi NBD (nilai batas dosis) yang telah ditetapkan. Dengan tidak menggunakan pemantauan dosis paparan radiasi $(\mathrm{fi} / \mathrm{m}$ badge), pekerja radiasi mempunyai potensi resiko besar terhadap paparan radiasi, karena kontrol pengendalian paparan radiasi dasamya adalah nilai besaran dalam satuan miuSv yang diterima oleh pekerja setiap bulan melalui film badge, dan nilai batas dosis yang diterima oleh pekerja tidak boleh melebihi 0,416 miuSv dalam satu bulan (Badan Pengawas Tenaga Nuklir No: 01-P/Ka-Bapeten/VI99). Mengingat efek dari radiasi sinar- $X$ yang dapat membahayakan kesehatan pada pekerja, maka pemantauan dosis personal terhadap pekerja merupakan suatu keharusan dilakukan (Hipkin \& Payter, 1999). Karena diyakini bahwa limfosit sangat sensitif terhadap radiasi, sehingga dapat mewakili dosis intema paparan radiasi pada pekerja. Mengingat analisis pada sel limfosit mempunyai banyak kelemahan dan subyektifitas terhadap penghitungan maka perlu ditunjang dengan pemeriksaan pada sistem hematopoitik yang lain yang memiliki radiosensitif terhadap sinar-X, di antaranya: jumlah total leukosit, limfosit, monosit, eosinofil, basofil, neutrofil, total eritrosit, PCV, hemoglobin, trombosit (Winarto, 2000).
Pada sistem hematopoitik, sel limfosit sangat sensitif terhadap radiasi sinar- $\mathrm{X}$, dan akibat induksi radiasi dapat terjadi penurunan jumlah dalam waktu 1 sampai 3 jam setelah terpapar radiasi. Dan sel darah merah kurang sensitif terhadap radiasi, namun jika sudah terjadi penurunan dari sel darah merah berarti pekerja sudah beresiko besar untuk terjadi gangguan kesehatan, baik efek stokastik maupun efek deterministik (Lukman, 2008). Paparan radiasi sinar-X di istalasi radio diagnostik tidak terlepas dari sistem pengendalian bahaya terhadap radiasi di lingkungan kerja. Sistem pengendalian bahaya radiasi tersebut meliputi: kalibrasi alat X-Ray sebagai sumber radiasi, dengan tujuan untuk mengetahui besaran kebocoran dari alat tersebut. Akibat kebocoran tersebut dapat dikeluarkan sinar hambur yang dapat mengenai pekerja, untuk itu pemantauan dosis radiasi di lingkungan kerja perlu juga dilakukan pengukuran, dengan tujuan apakah sinar hambur tersebut dapat diserap sepenuhnya oleh materi atau perisai. Sinar hambur yang masih dapat menembus materi tersebut mempunyai potensi untuk dapat mengenai pekerja operator radiologi.

Salah satu solusi atau upaya yang dilakukan saat ini adalah dengan pemantauan radiasi di lingkungan kerja yang dimaksudkan untuk tujuan penekanan peneriamaan dosis radiasi pada pekerja, agar dosis yang diterima pekerja operator radiologi tidak melebihi nilai batas dosis yang telah ditentukan (Siemens, 2003). Untuk menghindari kemungkinan buruk yang tidak diinginkan, para pekerja radiasi harus mendapatkan pelayanan pemantauan dosis perotangan selama menjalankan tugasnya. Dengan program pemantauan dosis pekerja secara ketat, penerimaan dosis oleh para pekerja radiasi akan tetap terkontrol dan dapat diambil tindakan proteksi secepat mungkin apabila jumlah penerimaan dosis akumulasinya melampaui nilai batas dosis yang telah ditetapkan (BAPETEN, 2001).

\section{METODE}

Merupakan penelitian analitik observasional dengan pengambilan data secara cross sectional study yaitu menganalisis kelainan pada sistem hematopoitik, jumlah total leukosit, limfosit, monosit, neutrofil, eosinofil, basofil, total eritrosit, PCV, hemoglobin, trombosit pada petugas yang terpapar radiasi dan membandingkan hasil analisis sistem hematopoitik pada petugas yang tidak terpapar radiasi, untuk mendapatkan gambaran tingkat keterpaparan radiasi pada petugas operator radiologi, di instalasi radiodiagnostik RSU Dr Wahidin Sudiro Husodo Kodya Mojokerto. 
Setelah dilakukan screening diperoleh sejumlah sample sebanyak 12 orang dengan pembagian kelompok 7 orang pekerja yang terpapar radiasi dan 5 orang pekerja yang tidak terpapar radiasi. Karakteristik sample meliputi semua pekerja yang terpapar radiasi (operator) radiologi, sebagai kelompok penelitian dan petugas yang tidak terpapar radiasi sebagai kelompok pembanding. Subyek dalam penelitian ini adalah semua pekerja yang bertugas di instalasi radiodiagnostik RSU Dr Wahidin Sudiro Husodo.

Penelitian dilakukan pada Bulan Juni 2010 di instalasi radiodiagnostik RSU Dr Wahidin Sudiro Husodo.

Pemeriksaan jumlah total leukosit, limfosit, monosit, neutrofil, eosinofil, basofil, total eritrosit, $\mathrm{PCV}$, hemoglobin, trombosit dengan menggunakan metode impedance dan photometri dengan menggunakan alat SYSMEX KX-21. Data yang diambil meliputi data primer dan data sekunder. Data primer meliputi hasil dari pemeriksaan hematopoitik pada kelompok penelitian (pekerja yang terpapar radiasi) dan kelompok pembanding (pekerja yang tidak terpapar radiasi), meliputi jumlah total leukosit, limfosit, monosit, neutrofil, eosinofil, basofil, total eritrosit, PCV, hemoglobin, trombosit. Data sekunder meliputi hasil pemetaan (mapping) dengan pengukuran paparan radiasi di lingkungan kerja radiologi. Pengukuran paparan sinar hambur di lingkungan sekitar pesawat X-Ray, ruangan operator/sheilding, dan tempat lain. Pengukuran dilakukan secara berkala dengan melakukan kalibrasi terhadap pesawat XRay setiap setahun sekali, dan untuk tindakan pengendalian di setiap Instalasi Radio Diagnostik harus ditempatkan alat pengontrol tingkat paparan di daetah kerja yang dinamakan survey meter.

Data primer dari analisis hematopoitik yang meliputi jumlah total leukosit, limfosit, monosit, neutrofil, eosinofil, basofil, total eritrosit, PCV, hemoglobin, trombosit, selanjutnya diolah dan dianalisis dengan uji $\mathrm{T}$ dua sample bebas untuk mengetahui perbedaan yang bermakna pada kelompok yang terpapar dan kelompok yang tidak terpapar. Data sekunder dari hasil pemetaan (mapping) dan pengukuran paparan sinar hambur radiasi lingkungan kerja diolah dan dianalisis secara deskriptif dan analitik untuk mengetahui besaran dosis sinar hambur di lingkungan kerja dan mempelajari apakah kebocoran dari alat $\mathrm{X}$ Ray dan paparan radiasi lingkungan kerja ada keterkaitannya dengan hasil analisis hematopotik.

\section{HASIL DAN PEMBAHASAN}

\section{Hasil}

\section{Karakteristik Responden}

Distribusi responden berdasarkan umur terbanyak pada kelompok umur 20-30 tahun (57\%). Distribusi umur pada kelompok kontrol terbanyak pada kelompok umur 20-30 tahun (60\%). Jenis kelamin responden yang banyak adalah laki-laki $(71 \%)$ dan wanita $(29 \%)$. Pada kelompok kontrol jenis kelamin terbanyak adalah laki-laki ( $80 \%$ ) dan wanita ( $20 \%)$. Sehingga penelitian ini didominasi oleh laki-laki. Masa kerja responden terendah adalah 1-5 tahun, mencapai $(43 \%)$ dan tertinggi 15-20 tahun, mencapai (14\%). Masa kerja kelompok kontrol terendah adalah 1-5 tahun, mencapai $(60 \%)$ dan tertinggi $21-25$ tahun, mencapai $(20 \%)$. Kemudian, frekuensi paparan responden yang banyak adalah $10-12 \mathrm{kali} / \mathrm{hari}$, mencapai $(43 \%)$ dan terendah 1-3 kali/hari, mencapai (14\%). Rata-rata frekuensi paparan responden adalah $7,4 \pm 2,7 \mathrm{kali} / \mathrm{hari}$.

\section{Pengukuran Sinar Hambur}

\section{Sinar Hambur Di Lingkungan Kerja Dan Ruang Operator}

Dari tabel 2 didapatkan bahwa sinar hambur yang telah terdeteksi oleh survey meter di masingmasing area pada saat masing-masing dari pesawat X-Ray bekerja.

\section{Pemetaan (Mapping) Sinar Hambur Di Instalasi Radiologi RSU Dr Wahidin Sudiro Husodo}

Dari gambar 1 didapatkan bahwa pengukuran sinar hambur dilakukan pada dacrah di mana terdapat pekerja, penderita dan masyarakat umum. Perbedaan nilai dosis dikarenakan sinar- $\mathrm{X}$ telah melalui proteksi (dinding dengan berlapis PB $2 \mathrm{~mm}$ ), sehingga pada luar area garis merah (area 3 ) dosis radiasi relatif lebih rendah dibandingkan dengan di dalam area garis merah (area 1 dan area 2) (dekat dengan pesawat X-Ray).

\section{Analisa Sel Darah}

Distribusi Jumlah Sel Leukosit (dalam ribu/uL), Jumlah Sel Limfosit (dalam \%), Jumlah Sel Monosit (dalam \%), Jumlah Sel Neutrofil (dalam \%), Jumlah Sel Eosinofil (dalam \%).

Dari tabel 3 didapatkan bahwa rerata total leukosit pada kelompok terpapar lebih rendah dari kelompok kontrol, tetapi secara statistik tidak bermakna, di mana $p>0,05$ yang berarti hasil secara 
nyata dari pemeriksaan sistem hematologi (leukosit) ternyata pada kelompok terpapar (radiografer) lebih rendah dari kelompok kontrol (orang yang tidak terpapar), namun secara statistik perbedaan tersebut tidak bermakna. Pada distribusi jumlah limfosit didapatkan bahwa rerata limfosit pada kelompok terpapar lebih tinggi dari kelompok kontrol, tetapi secara statistik tidak bermakna, di mana $\mathrm{p}>0,05$. Pada kelompok terpapar terdapat salah satu responden, yang hasil jumlah limfositnya sangat rendah $(22 \%)$, hasil tersebut lebih rendah dari nilai normal range $(25-40 \%)$ yang berarti secara keseluruhan hasil analisis hematologi (limfosit) pada kelompok terpapar (radiografer) lebih rendah dari kelompok kontrol. Pada kelompok terpapar ada salah satu responden yang nilai limfosit terendah $22 \%$ (nilai normal limfosit adalah $25-40 \%$ ). Pada distribusi jumlah monosit didapatkan bahwa rerata monosit pada kelompok terpapar lebih tinggi dari kelompok kontrol, tetapi secara statistik tidak bermakna, di mana $\mathrm{p}>$ 0,05 yang berarti hasil secara nyata dari pemeriksaan system hematologi (monosit) ternyata pada kelompok terpapar (radiografer) lebih tinggi dari kelompok kontrol (orang yang tidak terpapar), namun secara statistik perbedaan tersebut tidak bermakna. Pada distribusi jumlah neutrofil didapatkan bahwa rerata neutrofil pada kelompok terpapar lebih rendah dari kelompok kontrol, tetapi secara statistik tidak bermakna, di mana $p>0,05$. Pada distribusi jumlah eosinofil didapatkan bahwa rerata cosinofil pada kelompok terpapar lebih tinggi dari kelompok kontrol, dan secara statistik ada hubungan bermakna, di mana $\mathrm{p}>0,05$.

Distribusi Jumlah Sel Basofil (dalam \%), Jumlah Sel Eritrosit (juta/uL), Jumlah Sel PCV (dalam $\%)$, Jumlah Sel Hb (g/dl), Jumlah Sel Trombosit (ribu/uL).

Dari tabel 4 didapatkan bahwa rerata basofil pada kelompok terpapar sama dengan kelompok kontrol, tetapi secara statistik tidak tidak dapat diuji karena nilai 0 . Pada distribusi jumlah eritrosit didapatkan bahwa rerata eritrosit pada kelompok terpapar lebih rendah dari kelompok kontrol, tetapi secara statistik tidak bermakna, di mana $\mathrm{p}>0,05$. Pada distribusi jumlah PCV didapatkan bahwa rerata PCV pada kelompok terpapar lebih rendah dari kelompok kontrol, tetapi secara statistik tidak bermakna, di mana $\mathrm{p}>0,05$. Pada distribusi jumlah $\mathrm{Hb}$ didapatkan bahwa rerata $\mathrm{Hb}$ pada kelompok terpapar lebih rendah dari kelompok kontrol, tetapi secara statistik tidak bermakna, di mana $\mathrm{p}>0,05$. Pada kelompok terpapar terdapat salah satu responden, yang hasil jumlah $\mathrm{Hb}$ sangat rendah $(11,3$ $\mathrm{g} / \mathrm{dl}$ ), hasil tersebut lebih rendah dari nilai normal range (11,7-15,5 g/dl). Pada distribusi jumlah trombosit didapatkan bahwa rerata trombosit pada kelompok terpapar lebih tinggi dari kelompok kontrol, tetapi secara statistik tidak bermakna, di mana $\mathrm{p}>0,05$.

\section{Pembahasan}

Dari hasil penelitian tampak bahwa sebagian besar umur responden adalah antara 20-30 tahun, sehingga responden dalam penelitian ini didominasi kelompok umur muda $(57 \%)$. Variabel umur antara responden dengan kontrol tidak ada perbedaan yang bermakna. Demikian juga variabel umur tidak ada perbedaan bermakna terhadap jumlah kompartemen darah. Untuk jenis kelamin pada penelitian ini didominasi oleh laki-laki mencapai 9 orang $(75 \%)$, masing-masing 5 orang ( $71 \%$ ) pada responden dan 4 orang $(80 \%)$ pada kontrol, sehingga penelitian ini didominasi oleh kelompok laki-laki. Bila ditinjau dari prosentase yang mengalami penurunan jumlah kompartemen darah, didominasi oleh kelompok wanita mencapai $100 \%$ dari semua responden wanita mengalami penurunan jumlah kompartemen darah. Sedangkan untuk masa kerja pada penelitian ini didominasi oleh masa kerja 1-5 tahun, 6-10 tahun dan $11-15$ tahun, masing-masing 2 (dua) responden ( $29 \%$ ), sehingga penelitian ini didominasi oleh tiga kelompok masa kerja. Untuk variabel masa kerja dengan penghitungan jumlah kompartemen darah tidak ada perbedaan bermakna. Bila ditinjau dari prosentase yang mengalami penurunan jumlah kompartemn darah, didominasi oleh kelompok masa kerja 1-5 tahun.

Untuk variabel frekuensi paparan tidak ada perbedaan bermakna terhadap jumlah kompartemen darah. Bila ditinjau dari frekuensi paparan terhadap penurunan kompartemen darah maka, yang mengalami penurunan jumlah kompartemen darah terjadi pada responden dengan frekuensi paparan antara 10-12 kali/hari. Masing-masing responden dengan frekuensi paparan $8 \mathrm{kali} /$ hari mengalami 3 (tiga) jenis penurunan jumlah kompartemen darah, dan frekuensi paparan 4 dan 12 kali/hari mengalami penurunan 1 (satu) jenis kompartemen darah. Secara umum, makin banyak frekuensi paparan, akan semakin besar dosis yang diterima. Hasil tersebut membuktikan bahwa banyaknya frekuensi paparan tidak menentukan jumlah efek yang ditimbulkan, akan tetapi faktor kualitas dari sinar-X dan frekuensi paparan kemungkinan akan mempengaruhi jumlah kompartemen darah, namun hal ini harus ditinjau kembali besaran dosis yang diterima responden dalam 1 (satu) kali frekuensi. Hal ini terbukti bahwa responden dengan frekuensi 
Tabel 1. Pengukuran kebocoran pesawat X-Ray

\begin{tabular}{|c|c|c|c|}
\hline \multirow{2}{*}{$\begin{array}{c}\text { Jenis } \\
\text { pesawat }\end{array}$} & $\begin{array}{c}\text { Tingkat kebocoran pesawat } \\
\text { X-Ray }\end{array}$ & $\begin{array}{l}\text { Tingkat kebocoran sinar } \\
\text { hambur lingkungan kerja }\end{array}$ & Nilai batas dosis \\
\hline & $\begin{array}{ll}\text { Terendah } & \text { Tertinggi } \\
\overline{\mathrm{X}} 1\end{array}$ & Terendah Tertinggi $\overline{\mathrm{X}} 2$ & \\
\hline $\begin{array}{l}\text { OX } 110-1 / \\
1050104\end{array}$ & $\begin{aligned} 0,91 \mu \mathrm{Sv} / \mathrm{Jam} \quad & 13,68 \\
& \mu \mathrm{Sv} / \mathrm{Jam}\end{aligned}$ & $\begin{array}{cc}=0,1 & 0,23 \\
\mu \mathrm{Sv} / \mathrm{Jam} & \mu \mathrm{Sv} / \mathrm{Jam} \\
\text { (BG) } & \end{array}$ & $\begin{array}{l}\text { Dalam batas yang } \\
\text { diperkenankan }\end{array}$ \\
\hline $\begin{array}{c}\text { D-081/ } \\
5 \mathrm{~F} 88622\end{array}$ & Dental X-Ray & $\begin{array}{ccc}=0,1 & =0,1 \\
\mu \text { Sv/Jam } & \mu \text { Sv/Jam } & \\
\text { (BG) } & \text { (BG) } & 1,45 \\
& & \text { uSv }\end{array}$ & $\begin{array}{l}\text { Dalam batas yang } \\
\text { diperkenankan }\end{array}$ \\
\hline $\begin{array}{c}\mathrm{X} 22130 / 16 / \\
131394\end{array}$ & $\begin{array}{cc}=0,1 \mu \text { Sv/Jam } & 0,23 \\
\text { (BG) } & \mu \text { Sv } / \text { Jam }\end{array}$ & 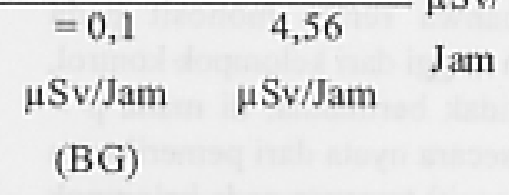 & $\begin{array}{l}\text { Dalam batas yang } \\
\text { diperkenankan }\end{array}$ \\
\hline $\begin{array}{c}\text { DR-1735 5KQ } \\
593\end{array}$ & $\begin{array}{lc}0,34 \mu \mathrm{Sv} / \mathrm{Jam} & 3,42 \\
& \mu \mathrm{Sv} / \mathrm{Jam}\end{array}$ & $\begin{array}{cc}=0,1 & 0,91 \\
\mu \mathrm{Sv} / \mathrm{Jam} & \mu \mathrm{Sv} / \mathrm{Jam} \\
(\mathrm{BG}) & \end{array}$ & $\begin{array}{l}\text { Dalam batas yang } \\
\text { diperkenankan }\end{array}$ \\
\hline
\end{tabular}

Tabel 2. Sinar hambur di lingkungan kerja dan ruang operator

\begin{tabular}{|c|c|c|c|c|c|c|}
\hline \multirow[t]{3}{*}{ Jenis pesawat } & \multicolumn{6}{|c|}{ Tingkat kebocoran sinar hambur lingkungan kerja } \\
\hline & \multicolumn{2}{|c|}{ Pintu pasien } & \multicolumn{2}{|c|}{ Pintu petugas } & \multicolumn{2}{|c|}{ Ruang operator } \\
\hline & $\mathbf{N}$ & Rata-rata & $\mathbf{N}$ & Rata-rata & $\mathrm{N}$ & Rata-rata \\
\hline OX $110-1 / 1050104$ & BG & $\leq 0,1$ & 0,23 & 0,33 & BG & 0,37 \\
\hline D-081/5F88622 & $\mathrm{BG}$ & $\mu \mathrm{Sv} / \mathrm{Jam}$ & BG & $\mu \mathrm{Sv} / \mathrm{Jam}$ & BG & $\mu \mathrm{S} v / \mathrm{Jam}$ \\
\hline $\mathrm{X} 22130 / 16 / 131394$ & . & (BG) & - & & - & \\
\hline DR-1735 5KQ 593 & BG & & 0,68 & & 0,91 & \\
\hline
\end{tabular}

Keterangan:

$\mathrm{BG}=\leq 0,1 \mu \mathrm{Sv} / \mathrm{Jam}$ 


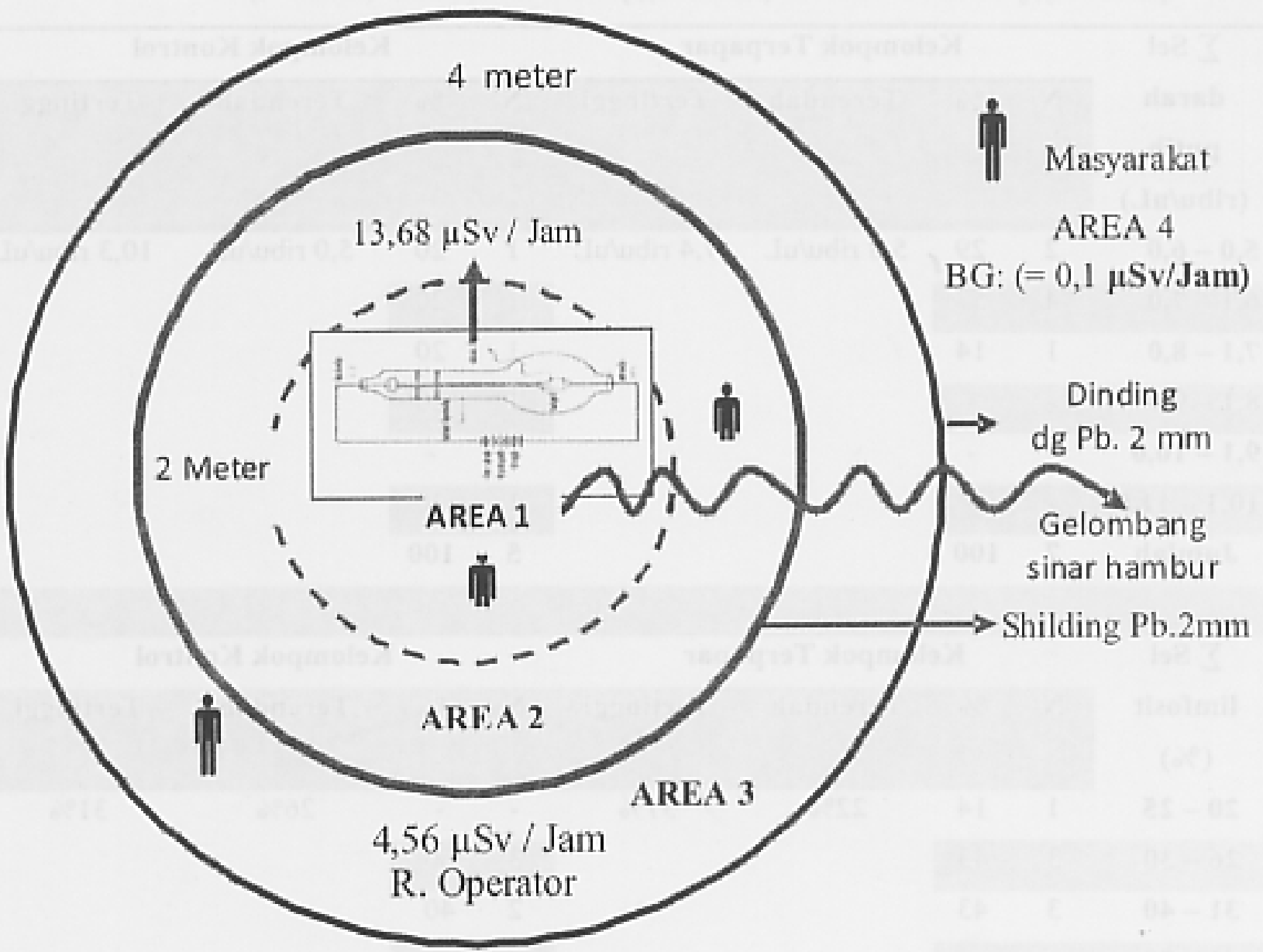

Gambar 1. Pemetaan (mapping) sinar hambur di Instalasi Radiologi RSU Dr Wahidin Sudiro Husodo

paparan $8 \mathrm{kali}$ dan $12 \mathrm{kali} / \mathrm{hari}$ jumlah analisis kompartemen darahnya lebih rendah dari pada yang frekuensi paparannya $<8 \mathrm{kali} / \mathrm{hari}$.

Dari hasil penelitian pada analisis jumlah total sel leukosit pada responden dan kelompok kontrol tidak ada perbedaan yang bermakna, namun hasil rata-rata antara responden dengan kontrol lebih tinggi pada kelompok kontrol ( 6,6 ribu/uL dengan 7,48 ribu/uL), walaupun nilai tersebut masih dalam nilai normal range baik untuk standar laki-laki maupun perempuan. Dari hasil analisis jumlah sel leukosit tersebut memberikan petunjuk bahwa, lebih rendahnya jumlah sel leukosit pada responden dimungkinkan karena ada hubungannya dengan faktor pekerjaan, baik frekuensi paparan, dosis, masa kerja dan sensitifitas terhadap radiasi. Dengan demikian menurunnya jumlah leukosit tersebut dapat dikatakan sebagai interprestasi dosis interna yang diterima oleh kelompok terpapar.

Jumlah sel limfosit responden dengan kelompok kontrol tidak ada perbedaan yang bermakna, dan jumlah rata-rata antara kedua kelompok tidak ada perbedaan yang signifikan (29,8\% dengan 29\%), hasil rata-rata kedua kelompok masih dalam nilai normal range (15-40\%). Hasil analisis jumlah limfosit pada responden yang terendah adalah $(22 \%)$ dan nilai ini lebih rendah dari nilai normal range (25$40 \%$ ), di mana responden tersebut berusia 35 tahun, masa kerja 4 tahun dengan frekuensi paparan radiasi $12 \mathrm{kali} / \mathrm{hari}$. Dimungkinkan bahwa sel limfosit responden tersebut lebih sensitif dibandingkan dengan responden yang lain. Walaupun nilai rata-rata masih dalam nilai normal range, karena masing-masing individu memiliki sensitifitas yang berbeda, sehingga pada individu yang memiliki radiosensitifitas maka hasilnya akan lebih rendah dari nilai rata-rata. Mengingat limfosit salah satu kompartemen darah yang paling sensitif terhadap radiasi, maka dengan bertambahnya waktu kerja, frekuensi paparan dan dosis akan memberikan efek yang lebih nyata, bukan hanya menurunnya jumlah sel limfosit saja namun 
Tabel 3. Distribusi jumlah sel leukosit (dalam ribu/uL), jumlah sel limfosit (dalam \%), jumlah sel monosit (dalam \%), jumlah sel neutrofil (dalam \%), jumlah sel cosinofil (dalam \%).

\begin{tabular}{|c|c|c|c|c|c|c|c|c|}
\hline$\sum$ Sel & \multicolumn{4}{|c|}{ Kelompok Terpapar } & \multicolumn{4}{|c|}{ Kelompok Kontrol } \\
\hline $\begin{array}{c}\text { darah } \\
\text { putih } \\
\text { (ribu/uL) }\end{array}$ & $\mathrm{N}$ & $\%$ & Terendah & Tertinggi & $\mathbf{N}$ & $\%$ & Terendah & Tertinggi \\
\hline $5,0-6,0$ & 2 & 29 & $5,8 \mathrm{ribu} / \mathrm{uL}$ & $7,4 \mathrm{ribu} / \mathrm{uL}$ & 1 & 20 & $5,0 \mathrm{ribu} / \mathrm{uL}$ & $10,3 \mathrm{ribu} / \mathrm{uL}$ \\
\hline $6,1-7,0$ & 4 & 57 & & & 1 & 20 & & \\
\hline $7,1-8,0$ & 1 & 14 & & & 1 & 20 & & \\
\hline $8,1-9,0$ & $=$ & - & & & 1 & 20 & & \\
\hline $9,1-10,0$ & - & - & & & - & - & & \\
\hline $10,1-11,0$ & 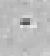 & - & & & 1 & 20 & & \\
\hline Jumlah & 7 & 100 & & & 5 & 100 & & \\
\hline
\end{tabular}

\section{$\sum$ Sel Kelompok Terpapar}

limfosit N $\%$ Terendah Tertinggi N \% (\%)

$\begin{array}{lll}\mathbf{2 0 - 2 5} & 1 & 14 \\ \mathbf{2 6 - 3 0} & 3 & 43 \\ \mathbf{3 1 - 4 0} & 3 & 43 \\ \mathbf{4 1 - 5 0} & - & \\ \text { Jumlah } & \mathbf{7} & \mathbf{1 0 0}\end{array}$

$\sum$ sel

Kelompok Terpapar
$26 \%$ $31 \%$
$22 \%$
$37 \%$
$-\quad-$
60
240

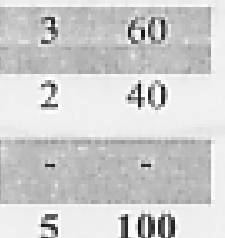
$5 \quad 100$

\begin{tabular}{|c|c|c|c|c|c|c|c|c|}
\hline$\sum$ sel & \multicolumn{4}{|c|}{ Kelompok Terpapar } & \multicolumn{4}{|c|}{ Kelompok Kontrol } \\
\hline monosit & $\mathbf{N}$ & $\%$ & Terendah & Tertinggi & N & $\%$ & Terendah & Tertinggi \\
\hline$(\%)$ & & & & & & & & \\
\hline 1 & - & - & \multirow[t]{5}{*}{$2 \%$} & \multirow{2}{*}{$4 \%$} & - & - & \multirow[t]{5}{*}{$3 \%$} & \multirow[t]{5}{*}{$2 \%$} \\
\hline 2 & 2 & 29 & & & 1 & 20 & & \\
\hline 3 & 2 & 29 & & & 4 & 80 & & \\
\hline 4 & 3 & 42 & & & - & - & & \\
\hline Jumlah & 7 & 100 & & & 5 & 100 & & \\
\hline$\sum$ sel & \multicolumn{4}{|c|}{ Kelompok Terpapar } & & \multicolumn{3}{|c|}{ Kelompok Kontrol } \\
\hline $\begin{array}{c}\text { neutrofil } \\
(\%)\end{array}$ & $\mathbf{N}$ & $\%$ & Terendah & Tertinggi & $\mathbf{N}$ & $\%$ & Terendah & Tertinggi \\
\hline $40-50$ & - & - & $52,0 \%$ & $69,0 \%$ & - & - & $60,0 \%$ & $65,0 \%$ \\
\hline $51-60$ & 4 & 57 & & & 1 & 20 & & \\
\hline $61-70$ & 3 & 43 & & & 4 & 80 & & \\
\hline
\end{tabular}


Tabel 4. Distribusi jumlah sel basofil (dalam \%), jumlah sel eritrosit (juta/uL), jumlah sel PCV (dalam \%), jumlah sel $\mathrm{Hb}(\mathrm{g} / \mathrm{dl})$, jumlah sel trombosit (ribu/uL).

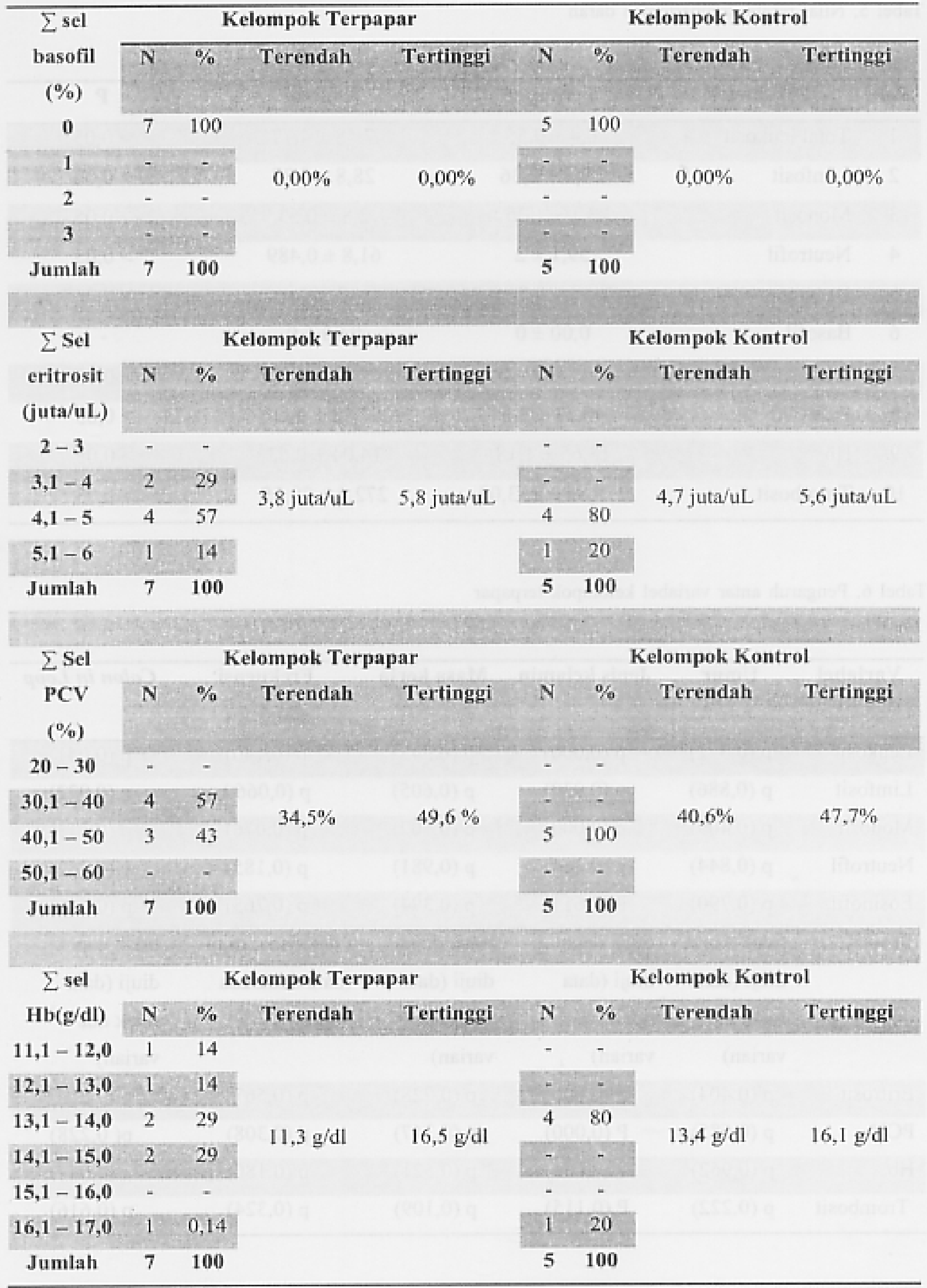


Tabel 5. Nilai rerata kompartemen darah

\begin{tabular}{clccc}
\hline No & Parameter & Terpapar & Kontrol & P \\
\hline 1 & Total leukosit & $6,4 \pm 0,55$ & $7,48 \pm 4,77$ & $>0,05$ \\
2 & Limfosit & $29,8 \pm 2,36$ & $28,8 \pm 0,87$ & $>0,05$ \\
\hline 3 & Monosit & $3,1 \pm 1,25$ & $2,8 \pm 0,53$ & $>0,05$ \\
4 & Neutrofil & $59,1 \pm 2$ & $61,8 \pm 0,489$ & $>0,05$ \\
\hline 5 & Eosinofil & $2,57 \pm 0,816$ & $2 \pm 0$ & $>0,05$ \\
\hline 6 & Basofil & $0,00 \pm 0$ & $0,00 \pm 0$ & $>0,05$ \\
7 & Eritrosit & $4,5 \pm 0,82$ & $4,96 \pm 0,339$ & $>0,05$ \\
8 & PCV & $40,21 \pm 2,3$ & $42,92 \pm 0,08$ & $>0,05$ \\
9 & Hb & $13,65 \pm 1,18$ & $14,04 \pm 0,63$ & $>0,05$ \\
\hline 10 & Trombosit & $279,85 \pm 153,03$ & $272,6 \pm 79,65$ & \\
\hline
\end{tabular}

Tabel 6. Pengaruh antar variabel kelompok terpapar

\begin{tabular}{|c|c|c|c|c|c|}
\hline Variabel & Umur & Jenis kelamin & Masa kerja & $\begin{array}{l}\text { Frekuensi } \\
\text { paparan }\end{array}$ & Colon in Loop \\
\hline Leukosit & $\mathrm{p}(0,322)$ & $p(0,000)$ & $\mathrm{p}(0,543)$ & $\mathrm{p}(0,140)$ & $\mathrm{p}(0,041)$ \\
\hline Limfosit & $\mathrm{p}(0,886)$ & $\mathrm{p}(0,930)$ & $\mathrm{p}(0,605)$ & $\mathrm{p}(0,066)$ & $\mathrm{p}(0,922)$ \\
\hline Monosit & $\mathrm{p}(0,409)$ & $\mathrm{p}(0,000)$ & $\mathrm{p}(0,507)$ & $p(0,076)$ & $\mathrm{p}(0,113)$ \\
\hline Neutrofil & $\mathrm{p}(0,844)$ & $\mathrm{p}(0,464)$ & $\mathrm{p}(0,981)$ & $\mathrm{p}(0,185)$ & $\mathrm{p}(0,752)$ \\
\hline Eosinofil & $\mathrm{p}(0,790)$ & $P(0,611)$ & $\mathrm{p}(0,394)$ & $\mathrm{p}(0,765)$ & $\mathrm{p}(0,846)$ \\
\hline \multirow[t]{4}{*}{ Basofil } & tidak dapat & tidak dapat & tidak dapat & tidak dapat diuji & tidak dapat \\
\hline & diuji (data & diuji (data & diuji (data & (data tidak ada & diuji (data \\
\hline & tidak ada & tidak ada & tidak ada & varian) & tidak ada \\
\hline & varian) & varian) & varian) & & varian) \\
\hline Eritrosit & $p(0,404)$ & $\mathrm{P}(0,000)$ & $p(0,728)$ & $p(0,567)$ & $p(0,214)$ \\
\hline $\mathrm{PCV}$ & $p(0,685)$ & $\mathrm{P}(0,000)$ & $\mathrm{p}(0,347)$ & $\mathrm{p}(0,308)$ & $p(0,228)$ \\
\hline $\mathrm{Hb}$ & $p(0,962)$ & $\mathrm{P}(0,000)$ & $p(0,521)$ & $\mathrm{p}(0,180)$ & $\mathrm{p}(0,044)$ \\
\hline Trombosit & $\mathrm{p}(0,222)$ & $\mathrm{P}(0,115)$ & $\mathrm{p}(0,109)$ & $\mathrm{p}(0,324)$ & $p(0,616)$ \\
\hline
\end{tabular}


Tabel 7. Pengaruh kuatnya hubungan antar variabel kelompok terpapar

\begin{tabular}{llllll}
\hline Variabel & Umur & Jenis kelamin & Masa kerja & \multicolumn{1}{c}{$\begin{array}{c}\text { Frekuensi } \\
\text { paparan }\end{array}$} & Colon in Loop \\
\hline Leukosit & $\mathrm{R}=-0,432$ & $\mathrm{R}=0,774$ & $\mathrm{R}=0,280$ & $\mathrm{R}=0,617$ & $\mathrm{R}=0,774$ \\
Limfosit & $\mathrm{R}=0,068$ & $\mathrm{R}=0,013$ & $\mathrm{R}=-0,201$ & $\mathrm{R}=-0,724$ & $\mathrm{R}=0,046$ \\
Monosit & $\mathrm{R}=-0,373$ & $\mathrm{R}=0,650$ & $\mathrm{R}=0,305$ & $\mathrm{R}=0,706$ & $\mathrm{R}=0,651$ \\
Neutrofil & $\mathrm{R}=-0,092$ & $\mathrm{R}=0,112$ & $\mathrm{R}=-0,011$ & $\mathrm{R}=0,566$ & $\mathrm{R}=0,148$ \\
Eosinofil & $\mathrm{R}=-0,125$ & $\mathrm{R}=0,078$ & $\mathrm{R}=0,385$ & $\mathrm{R}=-0,140$ & $\mathrm{R}=0,091$ \\
Basofil & tidak dapat & tidak dapat & tidak dapat & tidak dapat diuji & tidak dapat \\
& diuji (data & diuji (data & diuji (data & $($ data tidak ada & diuji (data \\
& tidak ada & tidak ada & tidak ada & varian) & tidak ada \\
& varian) & varian) & varian) & & varian) \\
Eritrosit & $\mathrm{R}=-0,377$ & $\mathrm{R}=0,570$ & $\mathrm{R}=-0,162$ & $\mathrm{R}=-0,264$ & $\mathrm{R}=0,537$ \\
PCV & $\mathrm{R}=-0,189$ & $\mathrm{R}=0,533$ & $\mathrm{R}=-0,421$ & $\mathrm{R}=-0,453$ & $\mathrm{R}=0,523$ \\
Hb & $\mathrm{R}=-0,022$ & $\mathrm{R}=0,781$ & $\mathrm{R}=-0,295$ & $\mathrm{R}=-0,572$ & $\mathrm{R}=0,767$ \\
Trombosit & $\mathrm{R}=-0,525$ & $\mathrm{R}=0,056$ & $\mathrm{R}=0,657$ & $\mathrm{R}=0,439$ & $\mathrm{R}=0,233$ \\
\hline
\end{tabular}

akan meberikan efek pada kompartemen darah yang lain. Dan diyakini bahwa responden tersebut dosis interna yang diterima dapat diinterprestasikan terhadap menurunnya kadar limfosit.

Dari analisis jumlah monosit antara responden dan kontrol tidak ada perbedaan yang bermakna, di mana nilai rata-rata adalah $(3,1 \%$ dan $2,8 \%)$. Dari hasil analisis jumlah rata-rata pada responden dan kelopok kontrol masih dalam nilai normal range (2$8 \%$ ). Hasil analisis jumlah neutrofil responden dengan kelompok kontrol nilai rata-rata tidak ada perbedaan bermakna $(59,1 \%$ dengan $61,8 \%)$. Hasil analisis jumlah neutrofil responden terendah ( $52 \%$ ) masih lebih rendah dari nilai rata-rata responden dan kelompok kontrol, hal ini memberikan petunjuk bahwa, jumlah kompartemen darah terendah responden masih di bawah kelompok kontrol. Rendahnya jumlah sel neutrofil pada responden erat kaitannya dengan faktor pekerjaan, walaupun nilai tersebut masih dalam nilai normal range.

Dari analisis jumlah eosinofil antara responden dan kontrol ada perbedaan yang bermakna, $(2,6 \%$ dan $2 \%$ ). Dari hasil analisis jumlah rata-rata pada responden dan kelopok kontrol masih dalam nilai normal range (2-4\%). Demikian juga untuk hasil terendah masih dalam nilai normal range. Hasil analisis jumlah sel basofil antara responden dengan kontrol menunjukkan nilai yang sama, di mana nilai normal range antara ( $(0-1 \%)$ dan tidak ada perbedaan yang bermakna. Di mana masing-masing kelompok memiliki jumlah yang relatif sama $(0,00 \%)$.

Hasil analisis jumlah sel eritrosit responden dengan kontrol secara kelompok tidak ada perbedaan yang bermakna. Sel eritrosit salah satu kompartemen darah yang kurang sensitif terhadap radiasi, jika responden jumlah sel eritrositnya lebih rendah dari nilai normal range, ada kemungkinan besaran dosis dan frekuensi paparan terhadap responden tersebut sangat besar atau ada faktor lain. Menurunnya kompartemen eritrosit pada responden tersebut pada kelompok paparan $8 \mathrm{kali} / \mathrm{hari}$ dan $4 \mathrm{kali} / \mathrm{hari}$. Dengan demikian frekuensi paparan bukan salah satu faktor penyebab menurunnya eritrosit, namun kualitas dari paparan sangat dimungkinkan menjadi bagian penyebab. Sehingga dapat disimpulkan bahwa dosis interna yang diterima oleh responden dapat dicerminkan pada sisitem biologi (sistem hematopoitik) dengan jumlah hitung eritrosit yang menurun. Karena masing-masing individu memiliki sensitifitas yang berbeda, sehingga pada individu yang memiliki radiosensitifitas, maka hasilnya akan lebih rendah dari nilai rata-rata. Mengingat eritrosit salah satu 
kompartemen darah yang kurang sensitif terhadap radiasi, dengan bertambahnya waktu kerja dan frekuensi dan kualitas paparan akan memberikan efek yang lebih jauh, bukan hanya menurunnya kuantitas eritrosit saja, namun akan memberikan efek menurunnya jumlah pada kompartemen darah yang lain, hingga timbunya efek stokastik dan efek deterministik.

Hasil analisis jumlah sel PCV responden dengan kontrol secara kelompok tidak ada perbedaan yang bermakna. Hasil rata-rata pada responden lebih rendah dari nalai rata-rata pada kelompok kontrol $(40,2 \%$ dengan $42,9 \%$ ). Dibandingkan dengan nilai normal range masih dalam batas nilai normal range, nilai terendah PCV pada responden adalah $(34,5 \%)$, pada responden berkelamin perempuan dengan frekuensi paparan $8 \mathrm{kali} /$ hari masih lebih rendah dari nilai normal range $(35-50 \%)$. Rendahnya hasil analisis kompartemn PCV pada responden, erat kaitanya dengan faktor pekerjaan responden. Hal ini harus menjadikan fokus perhatian, dengan tanpa mempertimbangkan nilai rata-rata masih dalam nilai normal range, karena masing-masing individu memiliki sensitifitas yang berbeda, sehingga pada individu yang memiliki radiosensitifitas maka hasilnya akan lebih rendah dari nilai rata-rata.

Hasil analisis jumlah sel hemoglobin ( $\mathrm{Hb}$ ) responden dengan kontrol secara kelompok tidak ada perbedaan yang bermakna. Hasil rata-rata pada responden lebih rendah dari nalai rata-rata pada kelompok kontrol (13,6 g/dl dengan $14,4 \mathrm{~g} / \mathrm{dl})$. Dibandingkan dengan nilai normal range masih dalam batas nilai normal range, namun pada responden nilai terendah $(11,3 \mathrm{~g} / \mathrm{dl})$ lebih rendah dari nilai normal range $(11,7 \mathrm{~g} / \mathrm{dl})$, dan ini terjadi pada responden jenis kelamin wanita, masa kerja 4 tahun dan frekuensi paparan $8 \mathrm{kali} / \mathrm{hari}$. Rendahnhya jumlah kompartemen $\mathrm{Hb}$ tersebut tergolong anemia fisiologis, karena responden wanita yang setiap bulan kehilangan darah melalui haid, namun penurunan $\mathrm{Hb}$ tidak harus diikuti menurunnya kompartemen darah yang lain. Jika diikuti penurunan jumlah kompartemen darah yang lain, maka harus dikaji terhadap hal-hal yang erat kaitanya dengan penyebab. Responden ini harus menjadikan fokus perhatian, dengan tanpa mempertimbangkan nilai rata-rata secara kelompok masih dalam nilai nomal range, karena masing-masing individu memiliki sensitifitas yang berbeda, sehingga pada individu yang memiliki radiosensitifitas maka hasilnya lebih rendah dari nilai rata-rata. Mengingat $\mathrm{Hb}$ merupakan bagian dari eritrosit, yang kurang sensitif terhadap radiasi, dengan bertambahnya waktu kerja, frekuensi paparan dan kualitas paparan akan memberikan efek yang lebih nyata, bukan hanya menurunnya kuantitas sel $\mathrm{Hb}$ saja, namun akan memberikan efek menurunnya jumlah pada kompartemen darah yang lain. Namun demikian masih perlu ditinjau lebih jauh jenis dari anemia yang diderita oleh responden, ada kemungkinan akibat defisiensi salah satu jenis nutrisi atau vitamin.

Hasil analisis jumlah sel trombosit responden dengan kontrol secara kelompok tidak ada perbedaan yang bermakna. Dari hasil analisis jumlah rata-rata pada responden dan kelompok kontrol masih dalam nilai normal range ( $150-440 \mathrm{ribu} / \mathrm{uL})$.

Dari hasil analisis statistik dengan menggunakan uji beda dengan $\mathrm{T}$ test bahwa secara bekelompok antara responden dengan kontrol tidak ada perbedaan yang bermana. Dari hasil penelitian dan analisis data pada sistem hematopoitik hanya variabel eosinofil responden dengan kontrol ada perbedaan bermakna dimana $\mathrm{p}<$ alfa, namun untuk jumlah kompartemen eosinofil kedua kelompok hasilnya masih dalam nilai normal range, dan secara kelompok dapat dikatakan hasilnya normal.

Hasil analisis data antara variabel frekuensi paparan dengan diagnostik colon in loop ada perbedaan bermakna terhadap beberapa kompartemen darah di antaranya jumlah total leukosit, neutrofil, eosinofil, PCV dan Hb. Dengan demikian menurunnya kompartemen darah tersebut pada beberapa responden diyakini ada hubungannya dengan pengoperasian pesawat X-Ray untuk diagnostik $\mathrm{co}$ lon in loop, atau dengan metode kontras. Menurut Price (2000) bahwa kelainan pada sistem hematopoitik akibat pajanan radiasi dapat terjadi pada setiap golongan umur, dosis dan sensitifitas sistem biologi sangat menentukan tingkat kerusakan biologis.

Semua Instalasi Radiodiagnostik diharapkan meningkatkan kewaspadaan terhadap bahaya radiasi, dan memberikan perlindungan kepada pekerja (PP 1 th 70), mengaktifkan tugas dan tanggung jawab pengelola Instalasi Radiodiagnostik melalui PPR (petugas proteksi radiasi), pemeriksaan kesehatan berkala dan melaksanakan sebaik-baiknya peraturan pemerintah Republik Indonesia nomor 33 tahun 2007 tentang keselamatan radiasi pengion dan keamanan sumber radioaktif.

\section{KESIMPULAN DAN SARAN}

Berdasarkan analisis data dan pembahasan seluruh rangkaian penelitian yang telah dilakukan, maka dapat disimpulkan bahwa: 1) Instalasi Radiodiagnostik harus dapat menjamin bahwa tingkat 
paparan radiasi di lingkungan kerja adalah aman, dengan melakukan pengukuran paparan radiasi secara berkala dengan kalibrasi terhadap pesawat X-Ray dan monitoring lingkungan kerja dengan survey meter. (Keputusan Kepala Badan Pengawas Tenaga Nuklir Nomor: 01/KA-BAPETEN/V-99. Di mana dosis lingkungan kerja adalah $<25$ miuSv miuSvjjam (2,5 mRem/Jam); 2) tingkat keterpaparan radiasi (dosis exposure) pada responden melalui analisis sistem hematologi adalah menurunnya jumlah komponen sel limfosit, eritrosit, PCV dan Hb. Diyakini bahwa kompartemen tersebut merupakan radiosensitif, dan tidak ada dosis yang aman akibat paparan radiasi, karena tubuh manusia dan sistem organ memiliki ambang sensitifitas yang berbeda; 3 ) dosimeter externa (film badge) masih belum cukup sebagai alat pemantau dosis exposure karena sensitifitas dan keakurasiannya belum dapat mewakili dosis exposure yang sebenarnya.

Saran yang dapat diberikan adalah: 1) menggunakan sarana monitoring personal yang lebih sensitif dan akurat yaitu TLD (thermo luminescence dosimeter) sebagai pengganti film badge, serta memperbaiki SOP (standar operasional prosedur) dalam setiap tindakan, dengan tetap mempertahankan nilai keamanan dalam pemanfaatan radiasi pengion; 2) melakukan pemeriksaan kesehatan secara berkala dengan monitoring sistem hematologi sebagai evaluasi dosis interna terhadap operator radiographer; 3 ) mempertahankan dan meningkatkan sistem proteksi radiasi yang telah ada dan mengevaluasi secara berkala; 4) perlu dilakukan penelitian lebih lanjut dengan sample yang lebih besar untuk mengetahui faktor yang berpengaruh terhadap dosis exposzore.

\section{DAFTAR PUSTAKA}

Akhadi \& Muhlis. 2002. Pancaran Sinar-X Karakteristik untuk Pemeriksaan Medis. Online.www.tempointeraktif.com. Diakses pada 28 Maret 2010.

Amptek. 2009. Mini-X is a Self-Contained Miniature X-Ray Tube System, which Includes the X-Ray Tube, High Voltage Supply, and USB Controller. Online www.amptek.com/minix j.png. Diakses pada 28 Maret 2010.

Badan Pengawas Tenaga Nuklir (BAPETEN). 2001. Materi Rekualifikasi Petugas Proteksi Radiasi Di Bidang Kesehatan Diagnostik. Jakarta.

Badan Tenaga Atom Nasional. 2002. Buku Pedoman
Proteksi Radiasi di Rumah Sakit dan Praktek Umum Lainnya. Jawa Barat: Depkes.

BATAN. 2006. "Multi Purpose Ractor G.A. Siawabessy", Safety Analysis Report, BATAN.

Broome, E.J., Brown, D.L., and Mitchel, R.E.J. 2000. Dose Response for Adaptaion to Low Doses of $60 \mathrm{Co}$ and $3 \mathrm{H}$-particle Radiation in Normal Human Fibroblast. ICPR and The International Radiation Protection Association.

Bushong, S.C. 1998. Radiologie Science for Technologists: Physics, Biology, and Protection. St.Louis: The C.V. Mosby Company.

Dasar-Dasar Pesawat Roengent. 2009. Online: Electromedical Engineering. blogspot.com. Diakses pada 12 Pebruari 2010.

Debertin, K., and Helmer, R.G. 2000. Gamma and XRay Spectrometry with Semiconductor Detectors. Amsterdam: North-Holland.

Departemen Kesehatan RI. 1991. Direktorat Instalasi Medik Direktorat Jenderal Pelayanan Medik. Buku Pedoman Pemeriksaan dan Paparan Radiasi Pesawat Radiodiagnostik. Cimahi Jawa barat.

Departemen Tenaga Kerja RI. 2001. Akademi Teknik Radiodiagnostik dan Radioterapi, Jaminan Kualitas (Quality Assurance) Radiodignostik. Bandung: BAPETEN.

Devvanda, B. 2008. Ionization Chamber. Online 4.bp.blogspot.com. Diakses pada 29 Maret 2010.

Hall, E. J. 2000. Radiobiology for the Radiobiologist. Philadelphia: JB Lippincott Company. 5 th Edition.

Halmshaw, R. 2008. Industrial Radiography. AgfaGevaert N.V: AGFA.

Heryudo, K. 2003. Peraturan Pemerintah Republik Indonesia Nomor 33, 2007.

Hipkin, J., Payter, R. A. 1999. Radiation Exposures to the Workforce from Natural Occurring Radioactivity in Industrial Processes, IAEA Vienna.

Hipkin, J., Payter, R.A. 1999. Radiation Protection Dosimetry. Vienna: IAEA.

IAEA. 1999. Practical Radiation Safety Manual, Manual on Shielded Enclosure, Incorporating Applications Guide, Procedure 
Guide, Basic Guide. IAEA-PPRSM-2 (Rev. 1). 1999. pp. 8-18.

INTERNATIONAL COMMISSION ON RADIATION UNITS AND MEASUREMENTS. 1999. Quantities and Units in Radiation Protection Dosimetry. Bethesda. MD.

Iskandar, E.R. 2003. Pengawasan Naturally Occuring Radioactive Material (NORM). Prosiding Seminar Aspek Keselamatan Radiasi dan Lingkungan. P.T. Widyadara hal. 14-21.

James, E.T. 1995. Atoms, Radiation, and Radiation Protection. IAEA-PPRSM-2 (Rev, 1). 1996. pp. 8-18.

Kanginan, M. 2000. Fisika Radiasi. Jakarta: Penerbit Erlangga.

Kusumo, H. 2002. Manajemen Sumber Radiasi yang Aman Konversi Nasional Keselamatan dan Kesehatan Kerja (K3) ke V. Jakarta.

Kusumo, H. 2002. Dampak Penerapan BSS terhadap Pengawasan Tenaga Nuklir di Indonesia. BATAN.

Lukman, D. 2008. Dasar-Dasar Radiology Dalam Ilmu Kedokteran. Jakarta: Widya Medika.

Martin, A. and Harbinson, A.S. 2008. An Introduction to Radiation Protection. London: Chapman and Hall.

Merrick, H. 1999. Sinar-X, Ilmu Pengetahuan Populer, Vol.10, Grolier International Inc./P.T. Widyadara hal. 144-151.

Sasaki, M.S., Ejima, Y., Tachibana, A. Y. T., Ishizaki, K., Shimizu, T., and Nomura, T. 2000. DNA Damage Response Pathway in Radioadaptive Response. The International Radiation Protection Association.

Siemens. 2003. Pengukuran Proteksi dan Paparan Radiasi. Jakarta: PT Siemens Indonesia.

Susilo, S.GB., Sminarto, K., Wahyu S.B., dan Yunita I. 2008. Digital Radiographs From XRay Fluoroscopy Screen System. Semarang: FMIPA UNDIP.

Sylvia, A.P. 2000. Patofisiologi Konsep Klinis Prosesproses penyakit, Jakarta: Buku kedokteran EGC.

Turniani, L. 2002. Efek Radiasi Pada Tubuh Manusia. Pusat Penelitian dan Pengembangan Pelayanan dan Teknologi Kesehatan Surabaya, Available at: http:/ www.tempo.co.id. Diakses pada 27 Januari 2010.
Winarto, K. 2000. Kedokteran Nuklir dan Aplikasi Teknik Nuklir dalam Kedokteran. Prosiding Presentasi Ilmiah Keselamatan Radiasi dan Lingkungan PSPKRBATAN. Jakarta, hal. 8-15.

Yudhi. 2009. Pengenalan Nuklir. www.infonuklir.com. Diakses pada 27 Januari 2010. 